\title{
Occurrence of parasites in Cobitidae from Croatian rivers draining into two different watersheds
}

\author{
By S. Zrnčić ${ }^{1}$, D. Oraić ${ }^{1}$, B. Šoštarić ${ }^{1}$, M. Ćaleta ${ }^{2}$ I. Bulj ${ }^{2}$, D. Zanella ${ }^{2}$ and D. Šurmanović ${ }^{3}$ \\ ${ }^{1}$ Croatian Veterinary Institute, Zagreb, Croatia; ${ }^{2}$ Department of Zoology, Faculty of Sciences, Zagreb, Croatia; ${ }^{3}$ Croatian Waters, \\ Department of Development, Zagreb, Croatia
}

\begin{abstract}
Summary
Members of the Cobitidae family are not economically important, thus few studies have been made on their pathology. A survey of parasitic fauna of some representatives of the loaches, such as Cobitis elongata, C. elongatioides, and the recently described C. bilineata, was carried out during the spring and summer of 2006. Fish samples were collected from four Croatian rivers: the Sava, Drava and Kupa draining into the Danubian system, and the Zrmanja draining into the Adriatic system. Specimens were of varying size, weight and age. Ectoparasitological examination revealed infections by the ciliate parasites Trichodina nigra $(61 ; 29 \%)$, Epistylis sp. (12; 9\%), Chilodonella cyprinid $(22 ; 58 \%)$, Ichthyophthyrius multifiliis $(81 ; 81 \%)$, dinoflagellate Piscioodinium pillulare (6; $45 \%$ ) and monogenean Gyrodactylus cobitis (22; 22\%). Histopathological examination of haematoxylin-eosin stained tissues showed the presence of Sarcocystis sp. in the muscle of one specimen. Dissections revealed an isolated finding of plerocercoid of Ligula colymbi in a Drava river specimen. A more comprehensive survey is necessary to determine the actual threat of the parasitoses to endangered species of the Cobitidae family.
\end{abstract}

\section{Introduction}

Species from the genus Cobitis are widespread in almost all European water systems, yet their distribution has been severely affected by anthropogenic factors. Loaches are also interesting model organisms for zoogeographic studies (Bohlen and Rab, 2001). Croatian rivers flow into two separate drainage systems: the Danubian and the Adriatic watersheds (Mrakovčić et al., 2000). Fish fauna in the Croatian section of the Danubian watershed are similar to those found in other parts of Europe and accommodate four species of the cobitid family: Cobitis elongata, C. elongatoides, Misgurnus fossilis and Sabanejewia balcanica. Rivers draining toward the Adriatic differ in length and either flow into lakes, the sea or disappear in karstic cavities; in this drainage system several loach species have been recognized: Cobitis dalmatina, $C$. nerentana and $C$. bilineata, the latter described for the first time by Buj et al. (2008).

Data on freshwater fish diseases are limited mostly to commercially important species. Loaches are hosts to numerous parasites and are affected by various diseases as well as acting as important secondary hosts for certain parasites (Koster et al., 2002). The presence of disease agents may influence the structure and size, feeding habits, growth rates and reproduction of loach populations. Few studies have been published on the parasite fauna of representatives of the genus Cobitis, describing the digenean parasite Allocreadium transversale in the intestines of $C$. taenia (Robotham and Thomas, 1982). Bychovskij (1962) and Bauer (1984) listed parasites observed in representatives of the genus Cobitis comprising parasitic protozoa and metazoa. The high intensity of infection in C. elongatoides by plerocercoids of the tapeworm Ligula colymbi as well as metacercariae of the trematode Posthodiplostomum cuticula in hybrids of $C$. elongatoides x $C$. sp. in the Czech Republic was observed by Halačka et al. (2000). Parasitological examination of $C$. elongatoides and hybrids of $C$. elongatoides and C. taenia in Poland revealed infections by six trematode species (Diplostomum sp., Echonostomatidae gen. sp., Tylodelphys clavata, Posthodiplostomum cuticula, Metorchis xanthosomus and Allocreadium transversale) and the nematode Rhabdochona ergensi (Popiolek and Kotusz, 2003, 2004; Popiolek et al., 2003). Scholz et al. (2004) reported the presence of the cestode Neogryporhynchus cheilancristrosus in C. tenia and M. fossilis.

Representatives of the genus Cobitis, with the goal of estimating their phylogenetic position and taxonomic status in both Croatian watersheds, were studied during the spring and summer of 2006. Samples of spined loach populations from several rivers were collected for investigation of their parasitofauna.

\section{Materials and methods}

Study area

Five sampling sites (Fig. 1) were included in the May, June and July 2006 study. From the Danubian watershed Site $1 \quad\left(45^{\circ} 16^{\prime} 08 / / \mathrm{N} ; \quad 16^{\circ} 55^{\prime} 17 / / \mathrm{E}\right)$ and Site $2\left(45^{\circ} 46^{\prime}\right.$ $\left.45 / / \mathrm{N} ; 16^{\circ} 01^{\prime} 00 / / \mathrm{E}\right)$ were at the Sava river, Site $3\left(45^{\circ} 26^{\prime} 49 / / \mathrm{N} ; 16^{\circ} 16^{\prime} 38 / \mathrm{E}\right)$ at the Kupa river, and Site 4 $\left(45^{\circ} 56^{\prime} 22 / \mathrm{N} ; 17^{\circ} 21^{\prime} 10 / / \mathrm{E}\right)$ at the Drava river; Site 5 $\left(44^{\circ} 11^{\prime} 59 / / \mathrm{N} ; 15^{\circ} 42^{\prime} 11 / \mathrm{E}\right)$ was at the Zrmanja river from the Adriatic watershed.

\section{Fish samples}

Representatives of the genus Cobitis were caught with nets at all sampling sites by electro fishing with a $7.5 \mathrm{~kW}$ generator during the spring and summer of 2006 (May through July). Live fish were placed in plastic containers with water from the sampling site and supplied with aeration during transport to the laboratory. Fish were killed by pithing the brain and immediately submitted to laboratory examination. Species determination was performed using colouration patterns and

\begin{tabular}{|c|c|c|c|c|c|c|}
\hline & \begin{tabular}{l|l|l}
$\mathbf{J}$ & $\mathbf{A}$ & $\mathbf{I}$ \\
\end{tabular} & \begin{tabular}{l|l|l|l}
1 & 1 & 9 & 2 \\
\end{tabular} & & Dispatch: 16.1 .09 & Journal: JAI & CE: Yasmin Begum \\
\hline & Journal Name & Manuscript No. & 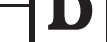 & Author Received: & No. of pages: 4 & PE: PUSHPA \\
\hline
\end{tabular}




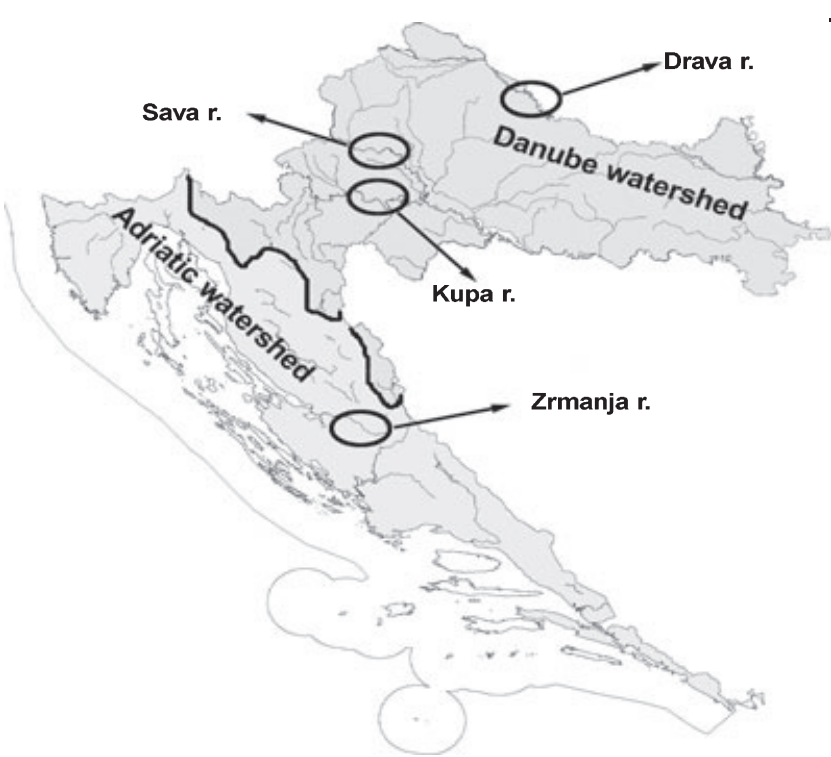

Fig. 1. Sampling sites (ovals) for cobitid species during the study period (May-July 2006) in rivers of two watersheds in Croatia. Solid line $=$ borderline of the watersheds

other morphological features according to determination keys of Vuković and Ivanović (1971), Povž and Sket (1990) and Maitland (2000). Total and standard lengths of each fish were measured in millimetres and the weight in grams. The ShapiroWilk test was used to test the null hypothesis as to whether data were normally distributed.

\section{Parasitological study}

Five representatives of the genus Cobitis were submitted for parasitological examination: two samples from the Sava river, and one each from the Kupa, Zrmanja and Drava rivers. Detailed parasitological examination was carried out immediately after sacrifice using the protocol of Marcogliese (1996). External organs (fins, skin, gills, and eyes) and internal organs (body cavity, heart, liver, spleen, swim bladder, stomach, gall and urinary bladders, gonads, digestive tract and contents) were examined first by dissecting microscope and subsequently with a compound microscope.

Specimens from each sample were fixed in $70 \%$ ethyl alcohol for parasitological examination and in $5 \%$ buffered formalin for histological examination. Formalin-fixed tissues were
2 subjected to standard histological procedures (True, 2001) and $6 \mu \mathrm{m}$ thick sections were placed on glass slides, stained by haematoxylin-eosin, covered with cover slips and examined by light microscopy. The determination of parasites was performed according to Bauer (1984), Lom and Dykova (1991), Moravec et al. (1991) and Bruno et al. (2006).

\section{Results}

Cobitis elongatoides specimens were collected at Sites 1 and 2 on the Sava river as well as on the Drava river (Site 4), while C. elongata specimens were sampled on the Kupa river (Site 3). From the Adriatic watershed only the Zrmanja river (Site 5) was included in the study, where a sample of $C$. bilineata was taken (Table 1). Total and standard lengths as well as weights of samples at Sites 1 and 2 collected in the Sava river and Site 4 from the Drava river were normally distributed $(\mathrm{P}>0.05)$, while weights of samples from Site 3 in the Kupa river and Site 5 in the Zrmanja river were not $(\mathrm{P}<0.05)$.

A total of 51 fish were examined; almost all were parasitized (Table 2). At sampling Site 1, 10 of 13 fish $(77 \%)$ were parasitized by the ciliates Trichodina nigra and Chilodonella cyprini and the dinoflagellate Piscioodinium pillulare. T. nigra was recorded in nine of $13(69 \%)$ fish, while $C$. cyprini was recorded in five of $13(38 \%)$. P. pillulare was present in three of $13(23 \%)$ fish. A mixed infection by T. nigra and C. cyprini was recorded in five of $13(31 \%)$, while $T$. nigra and $P$. pillulare were recorded in two of 13 $(15 \%)$ examined fish. The Sava river (Site 2) sample consisted of 11 fish; $10(91 \%)$ were parasitized either by the ciliate T. nigra or C. cyprini. The former was recorded in 10 of 11 $(91 \%)$ fish, whereby two $(18 \%)$ were also infected by C. cyprini. Histological examination of muscle tissue from a single specimen sampled at Site 2 showed lesions whereby various sections revealed multiple, large, basophilic cysts containing myriad dormant merozoites morphologically compatible with Sarcocystis sp. (Fig. 2). Adjacent muscle fibres were compressed, with individual fibres undergoing degeneration; however, no significant inflammatory or fibrosis tissue response was noted. The Cobitis elongata sample from the Kupa river (Site 3) consisted of 11 fish, nine (82\%) infected by varying developmental stages of Ichthyophthyrius multifiliis. On the Drava river (Site 4), seven specimens of C. elongatoides were collected; in one $(14 \%)$ fish a plerocercoid of the tapeworm Ligula colymbi was found in the body cavity, and four $(57 \%)$ fish were infected by the ciliate

Table 1

Cobitis species sampled at five sites in four rivers in Croatia; total (TL) and standard length (SL) and weight (w) with mean values, standard error (SE) and minimum-maximum value for each parameter

\begin{tabular}{|c|c|c|c|c|c|}
\hline $\begin{array}{l}\text { River } \\
\text { sampling } \\
\text { site }\end{array}$ & Species & $\mathrm{n}$ & $\begin{array}{l}\mathrm{TL}(\mathrm{mm}) \\
\mathrm{x} \pm \mathrm{SE} \\
(\text { range })\end{array}$ & $\begin{array}{l}\mathrm{SL}(\mathrm{mm}) \\
\mathrm{x} \pm \mathrm{SE} \\
\text { (range) }\end{array}$ & $\begin{array}{l}\mathrm{w}(\mathrm{g}) \\
\mathrm{x} \pm \mathrm{SE} \\
\text { (range) }\end{array}$ \\
\hline 1 & \multirow[t]{2}{*}{ C. elongatoides } & \multirow[t]{2}{*}{13} & $88.10 \pm 3.56$ & $78.2 \pm 3.0$ & $3.1 \pm 0.44$ \\
\hline Sava & & & $(69.4-111.4)$ & $(61.1-97.1)$ & $(1.2-6.3)$ \\
\hline 2 & \multirow[t]{2}{*}{ C. elongatoides } & \multirow[t]{2}{*}{11} & $70.1 \pm 3.88$ & $61.3 \pm 3.61$ & $1.9 \pm 0.3$ \\
\hline Sava & & & $(45.4-84.5)$ & $(39.7-74.3)$ & $(0.5-3.3)$ \\
\hline 3 & \multirow[t]{2}{*}{ C. elongata } & \multirow[t]{2}{*}{11} & $113.6 \pm 4.55$ & $98.9 \pm 4.06$ & 5.0 \\
\hline Kupa & & & $(95.6-137.7)$ & $(84.7-122.1)$ & $(3.1-9.6)$ \\
\hline 4 & \multirow[t]{2}{*}{ C. elongatoides } & \multirow[t]{2}{*}{7} & $66.6 \pm 3.54$ & $57.3 \pm 3.08$ & $1.7 \pm 0.29$ \\
\hline Drava & & & $(53.5-77.3)$ & $(45.8-66.5)$ & $(1.0-2.9)$ \\
\hline 5 & \multirow[t]{2}{*}{ C. bilineata } & \multirow[t]{2}{*}{9} & $57.7 \pm 3.52$ & $49.0 \pm 3.12$ & 0.82 \\
\hline Zrmanja & & & $(48.6-76.9)$ & $(40.7-67.4)$ & $(0.5-2.1)$ \\
\hline
\end{tabular}


Table 2

Overall prevalence of parasites in different Cobitis species sampled from four river systems in Croatia (see Fig. 1)

\begin{tabular}{lccc}
\hline Parasite & $\begin{array}{l}\text { C. elongatoides } \\
(\mathrm{n}=31)\end{array}$ & $\begin{array}{l}\text { C. elongata } \\
(\mathrm{n}=11)\end{array}$ & $\begin{array}{l}\text { C. bilineata } \\
(\mathrm{n}=9)\end{array}$ \\
\hline Piscioodinium pillulare & $6.45 \%$ & - & - \\
Trichodina nigra & $61.29 \%$ & - & - \\
Chilodonella cyprini & $22.58 \%$ & - & - \\
$\begin{array}{l}\text { Ichthyophthyrius } \\
\text { multifiliis }\end{array}$ & - & $81.81 \%$ & - \\
Epistiylis sp. & $12.90 \%$ & - & - \\
$\begin{array}{l}\text { Gyrodactylus cobitis } \\
\text { Ligula colymbi }\end{array}$ & - & - & $22.22 \%$ \\
\hline
\end{tabular}

$\mathrm{n}=$ number of specimen studied.

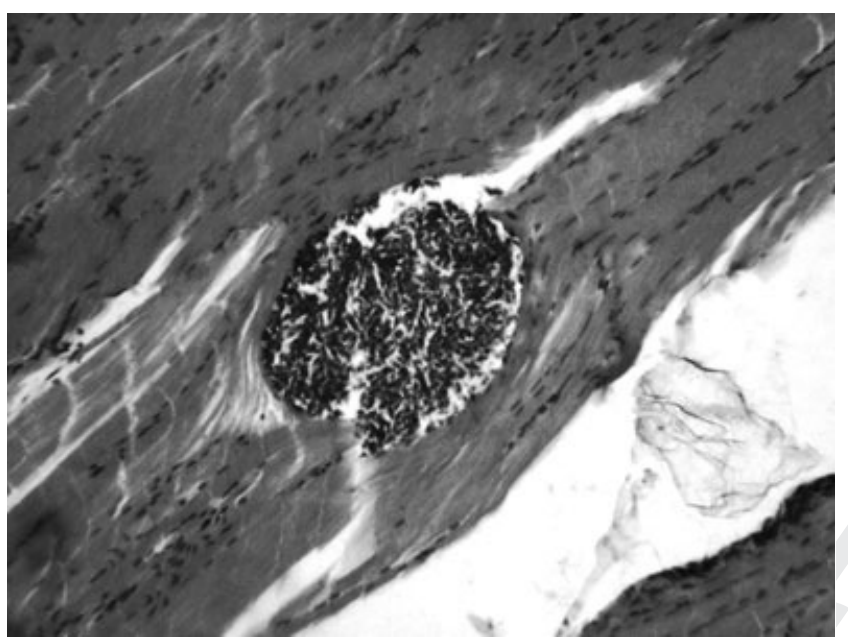

Fig. 2. Sarcocystis sp. in muscle of C. elongatoides from Sava river. Stage comprised of large tissue cysts containing thousands of dormant merozoites

Epistylis. At Site 5 on the Zrmanja river, nine Cobitis bilineata were examined; the monogenean Gyrodactylus cobitis was recorded on the skin of two fish $(22 \%)$. Although the gills as well as internal organs from all sampled fish were examined histologically, most tissues were within normal limits. In some specimens the fusion of lamellae, epithelial cells hyperplasia with the proliferation of adjacent connective tissues was noted.

\section{Discussion}

Parasites affect almost every conceivable level of biological organisms; generally, the importance of these abundant, species-rich and wide-spread life forms is not well known (Lindstrom et al., 1994). Recent research has also revealed that the species richness of Cobitis characterized by geographic diversity has established scientific interest in all aspects of their biology. Some of the species in this genus are considered as vulnerable to endangered, according to IUCN (1990) methodology. The question then arises as to what extent does the presence of parasites influence the vulnerability or abundance of a particular species?

The ectoparasites recorded in our study did not reveal pathological changes caused by their presence. As to the literature data, most papers deal with the description of endoparasitic helmints of different Cobitis species (Bauer,
1984; Moravec, 2001; Popiolek and Kotusz, 2004); monogenean G. cobitis was listed in reviews of Bychovskij (1962) and Moravec (2001). The different ciliates recorded in our specimens were either on the skin or the gills, similar to the finding of trichodinid from the gills of Cobitis taenia in the Rybinsk Reservoir, USSR (Arthur and Lom, 1984) or the list of parasites recorded in Cobitidae that includes Trichodina nigra (Bychovskij, 1962). To date, there are no records of digenean in representatives of the Cobitis species in Croatia, however, future research should comprise more regular sampling, with higher numbers of particular species.

It is known that cyprinid fish are secondary intermediate hosts for L. intestinalis, the occurrence of which in the host body cavity inhibits gonadal development and prevents reproduction (Carter et al., 2005). The finding of the plerocercoid of L. colymbi in C. elongatoides in the Czech Republic (Halačka et al., 2000) indicates that discovery of this parasite in C. elongatoides from the Drava river in Croatia is not an isolated case. A single finding of this parasite in C. elongatoides from the Drava river suggests the necessity of further research to determine its prevalence among the Cobitis population and the possible influence on gonadal development. Sarcocystis in the muscle of $C$. elongatoides from the Sava river was, until now, unknown; its prevalence and possible pathological impact on the host remains to be clarified. The lesions described in the histopathological examination of gills are non-specific and the possibility of parasitic ethiology should be further investigated.

It should be evaluated as to whether the parasitic load can additionally endanger the Croatian species of the genus Cobitis, as it is known that predators tend to catch prey infected with parasites more often than expected. Lafferty and Morris (1996) proved that herons prey substantially, up to 30 times more, on fish infected with digeneans that on uninfected fish.

The abundance of parasites may influence the number of predators a community can support (Skorping and Hogstedt, 2001). Therefore, parasite-induced trophic transmission deserves greater attention; future research should focus on the abundance of certain parasites and their possible cascade effect with regard to ecologists.

\section{References}

Arthur, J. R.; Lom, J., 1984: Trichodinid protozoa (Ciliophora: Peritrichida) from freshwater fishes in Rybinsk Reservoir, USSR. J. Eukaryot. Microbiol. 31, 82-91 (In English).

Bauer, O. N., 1984: Opredelitel' parazitov presnovodnyh ryb SSSR (Key of freshwater fish parasites of the SSSR fauna). Parasitic protozoan, Vol. I. Academy of Sciences, Leningrad, USSR, 431 p. (In Russian)

Bohlen, J.; Rab, P., 2001: Species - and hybrid richness in spined loaches (genus Cobitis L.) with a checklist of the species and hybrids of Europe. J. Fish Biol. 59a, 75-89.

Bruno, D. W.; Nowak, B.; Elliott, D. G., 2006: Guide to the identification of fish protozoan and metazoan parasites in stained tissue sections. Dis. Aquat. Org. 70, 1-36.

Buj, I.; Podnar, M.; Mrakovčić, M.; Choleva, L.; Šlechtová, V.; Tvrtković, N.; Caleta, M.; Mustafić, P.; Marčić, Z.; Zanella, D.; Brigić, A., 2008: Genetic diversity and phylogenetic relationships of spined loaches (genus Cobitis) in Croatia based on mtDNA and allozyme analyses. Folia Zool. 57, 71-83.

Bychovskij, B. E. (Ed.), 1962: Opredelitel' parazitov presnovodnyh ryb SSSR. [Key to the parasites of freshwater fishes of the USSR]. Academy of Sciences, Leningrad, Moskva, USSR, 776 p. (In Russian)

Carter, V.; Pierce, R.; Dufour, S.; Arme, C.; Hoole, D., 2005: The tapeworm Ligula intestinalis (Cestoda: Pseudophyllidea) inhibits 
LH expression and puberty in its teleost host, Rutilus rutilus. Reproduction 130, 939-945.

Halačka, K.; Luskova, V.; Lusk, S., 2000: Contribution to the occurrence of parasites in Cobitis elongatoides and Cobitis elongatoides x C. sp. Folia Zool. 49(Suppl. 1), 215-218.

IUCN, 1990: Red data list of threatened animals. IUCN, Gland, Switzerland and Cambridge, UK, 288 p. ISBN: 2831700310.

Koster, W. M.; Raadik, T. A.; Clunie, P., 2002: Scoping study of the potential spread and impact of the exotic fish Oriental weatherloach in the Murray-Darling Basin, Australia: A resource document. Freshwater Ecologyk Arthur Rylah Institute for Environmental Research. Heidelberg Victoria, Australia, 89 p.

Lafferty, K. D.; Morris, A. K., 1996: Altered behaviour of parasitized killy fish increases susceptibility to predation by bird final hosts. Ecology 77, 1390-1397.

Lindstrom, E. R.; Andren, H.; Angelstam, P., 1994: Disease reveals the predator; sarcoptic mange, redfox predation and prey populations. Ecology 75, 1042-1049.

Lom, J.; Dykova, I., 1991: Parasitic Protozoa. In: Diagnostic prevention and therapy of fish diseases and intoxications Z. Svobodova and B. Vykusova (Eds). Research Institute of Fish Culture and Hydrobiology, Vodnany, Czech Republic, 52 p. ISBN: 80-901087-0-9.

Maitland, P. S., 2000: Guide to Freshwater Fish of Britain and Europe. Julian Brown (Ed.). Hamlyn, London, 256 p. ISBN: 0600596907.

Marcogliese, D. J., 1996: EMAN. Protocols for measuring biodiversity: Parasites of fishes in freshwater. Parasitology Section, Canadian Society of Zoologists, Montreal, Quebec, Canada, 22 p.

Moravec, F., 2001: Checklist of the Metazoan Parasites of Fishes of the Czech Republic and the Slovak Republic (1873-2000). Academia, Praha. 168 p.

Moravec, F.; Ergens, R.; Našincova, V.; Scholz, T., 1991: Parasitic Metazoa. In: Diagnostic, prevention and therapy of fish diseases and intoxications. Z. Svobodova and B. Vykusova (Eds).
Research Institute of Fish Culture and Hydrobiology, Vodnany, Czech Republic, 152 p. ISBN: 80-901087-0-9.

Mrakovčić, M.; Scheider, D.; Mustafić, P.; Kerovac, M., 2000: Status of genus Cobitis and related species in Croatia. Folia Zool. 49(Suppl. 1), 113-116.

NWFHS, 2001: Laboratory Procedures Manuel. US Fish and Wildlife Service, Washington, D.C., 405 p.

Popiolek, M.; Kotusz, J., 2003: Endoparasitic helmints of fishes of the genus Cobitis from Poland. Folia Biol. (Krakow) 51(Suppl.), 173178.

Popiolek, M.; Kotusz, J., 2004: Metacercariae of digeneans occurring in Cobitis elongatoides Bacescu et Maier, 1969 (Pisces: Cobitidae). Wiad. Parazytol. 50, 609-613. (In Polish).

Popiolek, M.; Okulewicz, J.; Kotusz, J., 2003: The first record of Allocreadium transversale (Rudolphi, 1802) (Digenea, Allocreadiidae) from cobitid fishes of Poland. Helminthologia 40, 245246.

Povž, M.; Sket, B., 1990: Naše sladkovodne ribe. (Our freshwater fishes). Založba Mladinska knjiga, Ljubljana. Irena Trenc-Frelih (Ed.). 370 p. (In Slovenian).

Robotham, P. W. J.; Thomas, J. S., 1982: Infection of the spined loach, Cobitis taenia (L.), by the digenean, Allocreadium transversale (Rud.). J. Fish Biol. 21, 699-704.

Scholz, T.; Bray, R. A.; Kuchta, R.; Repova, R., 2004: Larvae of gryporhynchid cestodes (Cyclophyllidea) from fish: a review. Folia Parasitol. 51, 131-152.

Skorping, A.; Hogstedt, G., 2001: Trophic cascades: a role for parasites? Oikos 94, 191-192.

Vuković, T.; Ivanović, B., 1971: Slatkovodne ribe Jugoslavije. Zemaljski muzej BiH, Sarajevo. Željka Bjelčić (Ed.). 268 p. (In Serbo-Croatian).

Author's address: Snježana Zrnčić, Croatian Veterinary Institute, Department of Pathology, Savska 143, CR-10000 Zagreb, Croatia.

E-mail address: zrncic@irb.hr 


\section{Author Query Form}

\section{Journal: JAI}

Article: 1192

Dear Author,

During the copy-editing of your paper, the following queries arose. Please respond to these by marking up your proofs with the necessary changes/additions. Please write your answers on the query sheet if there is insufficient space on the page proofs. Please write clearly and follow the conventions shown on the attached corrections sheet. If returning the proof by fax do not write too close to the paper's edge. Please remember that illegible mark-ups may delay publication.

Many thanks for your assistance.

\begin{tabular}{|l|l|l|}
\hline $\begin{array}{l}\text { Query } \\
\text { reference }\end{array}$ & Query & Remarks \\
\hline Q1 & $\begin{array}{l}\text { AUTHOR: A running head short title was not supplied; please check if this } \\
\text { one is suitable and, if not, please supply a short title of up to } 40 \text { characters } \\
\text { that can be used instead. }\end{array}$ & \\
\hline Q2 & $\begin{array}{l}\text { AUTHOR: True, 2001 has not been included in the Reference List, please } \\
\text { supply full publication details. }\end{array}$ & \\
\hline Q3 & $\begin{array}{l}\text { AUTHOR: NWFHS, (2001) has not been cited in the text. Please indicate } \\
\text { where it should be cited; or delete from the Reference List. }\end{array}$ & \\
\hline Q4 & $\begin{array}{l}\text { AUTHOR: Please provide the name of the publisher, city location of } \\
\text { publisher for reference Povž; Sket (1990). }\end{array}$ & \\
\hline Q5 & $\begin{array}{l}\text { AUTHOR: Please provide the name of the publisher, city location of } \\
\text { publisher for reference Vuković; Ivanović (1971). }\end{array}$ & \\
\hline
\end{tabular}




\section{Please correct and return this set}

Please use the proof correction marks shown below for all alterations and corrections. If you wish to return your proof by fax you should ensure that all amendments are written clearly in dark ink and are made well within the page margins.

\begin{tabular}{|c|c|c|}
\hline Instruction to printer & Textual mark & Marginal mark \\
\hline Leave unchanged & ... under matter to remain & ( ) \\
\hline $\begin{array}{l}\text { Insert in text the matter } \\
\text { indicated in the margin }\end{array}$ & $h$ & $\begin{array}{l}\text { New matter followed by } \\
h \text { or } h \otimes\end{array}$ \\
\hline Delete & $\begin{array}{l}\text { I through single character, rule or underline } \\
\text { or }\end{array}$ & $\sigma$ or $\sigma(x)$ \\
\hline $\begin{array}{l}\text { Substitute character or } \\
\text { substitute part of one or } \\
\text { more word(s) }\end{array}$ & I through letter or & $\begin{array}{l}\text { new character / or } \\
\text { new characters / }\end{array}$ \\
\hline Change to italics & — under matter to be changed & $\leftarrow$ \\
\hline Change to capitals & $\equiv$ under matter to be changed & $\equiv$ \\
\hline Change to small capitals & $=$ under matter to be changed & $=$ \\
\hline Change to bold type & $\sim$ under matter to be changed & $\sim$ \\
\hline Change to bold italic & $\bar{\sim}$ under matter to be changed & $\underline{s i n}$ \\
\hline Change to lower case & Encircle matter to be changed & $\Rightarrow$ \\
\hline Change italic to upright type & (As above) & \\
\hline Change bold to non-bold type & (As above) & \\
\hline Insert 'superior' character & $\begin{array}{l}/ \text { through character or } \\
K \text { where required }\end{array}$ & $\begin{array}{l}y^{\prime} \text { or } y \\
\text { under character } \\
\text { e.g. } y^{2} \text { or } y^{2}\end{array}$ \\
\hline Insert 'inferior' character & (As above) & $\begin{array}{l}\lambda \\
\text { over character } \\
\text { e.g. } \hat{\Sigma}\end{array}$ \\
\hline Insert full stop & (As above) & $\odot$ \\
\hline Insert comma & (As above) & , \\
\hline Insert single quotation marks & (As above) & $\begin{array}{l}\dot{y} \text { or } \dot{x} \text { and/or } \\
\dot{y} \text { or } \dot{y}\end{array}$ \\
\hline Insert double quotation marks & (As above) & $\begin{array}{l}\ddot{y} \text { or } \ddot{y} \text { and/or } \\
\ddot{y} \text { or } \ddot{y}\end{array}$ \\
\hline Insert hyphen & (As above) & 1 \\
\hline Start new paragraph & 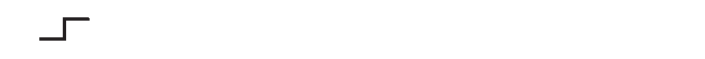 & 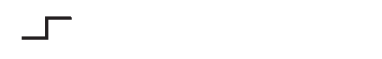 \\
\hline No new paragraph & $\infty$ & $\omega$ \\
\hline Transpose & $\sqcup$ & $\sqcup$ \\
\hline Close up & linking $\bigcirc$ characters & \\
\hline $\begin{array}{l}\text { Insert or substitute space } \\
\text { between characters or words }\end{array}$ & $\begin{array}{l}\text { I through character or } \\
\Lambda \text { where required }\end{array}$ & \\
\hline $\begin{array}{l}\text { Reduce space between } \\
\text { characters or words }\end{array}$ & $\begin{array}{l}\text { between characters or } \\
\text { words affected }\end{array}$ & $\uparrow$ \\
\hline
\end{tabular}

